\title{
Correction to: Special section on dental public health: a collaboration between the Canadian Journal of Public Health and the Canadian Association of Public Health Dentistry
}

\author{
Lindsay McLaren $^{1} \cdot$ Rafael Figueiredo ${ }^{2}$ \\ Published online: 20 July 2020 \\ (C) The Canadian Public Health Association 2020
}

Correction to: Can J Public Health. https://doi.org/10.17269/CJPH.108.6347

Rafael Figueiredo's name was incorrect in the original article; it is correct as displayed here.

Publisher's note Springer Nature remains neutral with regard to jurisdictional claims in published maps and institutional affiliations.

The online version of the original article can be found at https://oi.org/ 10.17269/CJPH.108.6347

Lindsay McLaren

lmclaren@ucalgary.ca

1 University of Calgary, Calgary, AB, Canada

2 Alberta Health Services, Edmonton, AB, Canada 